\title{
PROJECT DELAYS IN THE MALAYSIAN PUBLIC SECTOR: CAUSES, PATHOGENS AND THE SUPPLY CHAIN MANAGEMENT APPROACH
}

\author{
Salman Riazi Mehdi Riazi ${ }^{1 *}$, Mohd Nasrun Mohd Nawi ${ }^{2}$ \\ ${ }^{1}$ School of Housing, Building, and Planning, Universiti Sains Malaysia, 11800 USM, Penang, Malaysia \\ ${ }^{2}$ School of Technology Management and Logistics, University Utara Malaysia, 06010 Sintok, Kedah, \\ Malaysia
}

(Received: July 2018 / Revised: September 2018 / Accepted: December 2018)

\begin{abstract}
The inability to complete a project before its deadline has been a severe dilemma in Malaysian public sector projects. Despite initiatives introduced by the government to improve performance, few positive outcomes have been achieved due to inappropriate implementation and a lack of contemporary approaches. Past methods in delay studies have also fallen short in identifying the underlying causes of delays; thus, delay has remained an incessant phenomenon. Thus, this study was conducted in an attempt to shed light on the current delay scenario, taking the "pathogen" approach in identifying the very root of the causes of delay in an effort to propose a way forward for its mitigation via a contemporary approach known as Supply Chain Management (SCM). The research design that was adopted involved three stages. The first stage was an identification of factors that cause delay, whereby six industry experts with a minimum of 20 years of experience were interviewed to gain their insight on this matter. Then, the factors were grouped into pathogens and pathogen sub-categories using a concept taken from other prominent research that took a similar research approach. The third and final stage involved matching beneficial SCM tools that were carefully selected from a literature review that had the potential to overcome each of the delay pathogens and pathogen sub-categories. The conceptual framework, as concluded by this research, provides a thorough overview of the delay factors, pathogens, and pathogen sub-categories, as well as the available tools via SCM that could be used to overcome these issues. It is anticipated that this framework will lead to better time management in future Malaysian public sector construction projects.
\end{abstract}

Keywords: $\quad$ Delay; Malaysia; Pathogen; Public sector; Supply chain management (SCM)

\section{INTRODUCTION}

Success is undoubtedly the main objective of any business, including the construction sector. While success may be perceived differently depending on priorities, properly meeting time targets is generally accepted as an important indication of whether a job has been well-executed (e.g., Chan \& Chan, 2004). This face is evident in the context of construction projects, as time is regarded as the essence of each contract; thus, failure to complete a project on time can lead to numerous adverse effects. These effects may include extra costs due to increased overhead, loss of opportunity costs as capitals get trapped in unfinished work, and loss of revenueespecially if the project is commercial. While public sector projects may not be concerned with profitability aspects, delays can still lead to disturbing effects, such as tarnished reputations,

\footnotetext{
*Corresponding author's email: salman.riazi@usm.my, Tel. +6-04-6533888, Fax. +6-04-6576523 Permalink/DOI: https://doi.org/10.14716/ijtech.v9i8.2758
} 
failure to provide public amenities on time, and the government losing the public's trust.

In Malaysia, the construction industry is very important for the economy; however, poor time adherence often leads to major setbacks in this sense, especially in public sector projects. The ability of public sector projects to be completed on time has been very poor; it began deteriorating perhaps in the year 2000, in reference to a combination of findings by Abd Karim (2008), Joshi (2009), and Jatarona et al. (2016). While limited efforts have been made to gain insight into their incidence (e.g., Othman et al., 2006; Shehu et al., 2015), many past studies were ineffective in the sense that the underlying reasons were not identified (AlSehaimi et al., 2012). This fact motivated this paper to focus its delay studies on the "Pathogen" approach, which was described by Busby and Hughes (2004) as the underlying conditions concealed within a system that are unidentifiable as long as problems as a result of these conditions have yet to occur (Busby \& Hughes, 2004).

The main objective of this paper is to propose a conceptual supply chain management (SCM) framework in order to reduce the number and extent of delays in Malaysian public sector projects. With respect to the old-fashioned local construction industry (see Zaini, 2000; Nawi et al., 2010; Abd Shukor et al., 2011) that lacked contemporary approaches (e.g., Hamid \& Kamar, 2010) and the fact that SCM has been regarded by many researchers as the way forward for the industry (e.g., Egan, 1998; Love et al., 2004), this paper aims to develop a final framework by matching distinctive delay pathogens and pathogen sub-categories that are grouped using the same concept as Busby and Hughes (2004), with the SCM tools identified in the literature review as beneficial for overcoming each pathogen and pathogen sub-category. It is anticipated that this framework could provide a holistic guideline for delay mitigation via SCM efforts.

\section{OVERVIEW OF THE MALAYSIAN CONSTRUCTION INDUSTRY}

The Malaysian construction industry's ambition to progress was well-established even before Malaysia became independent in 1957. The construction industry has been the economic generator of many other industries (CIMP, 2007); its inaugural five-year economic plans were established as early as 1956 - the first one between 1956 and 1960 and the second one between 1961 and 1965. The subsequent plans that came along, until the recent and still ongoing plan known as the Eleventh Malaysia Plan (2016 to 2020), all aimed for well-scheduled development of the country (Mehdi Riazi \& Lamari, 2013). In addition, a variety of megaprojects have been initiated with the goal of promoting what Malaysia has to offer to the world, including its PETRONAS Twin Towers, the sustainable cities of Putrajaya and Cyberjaya, and the Sepang F1 Track. Also, some of Malaysia's projects have been given substantial monetary awards (i.e. RM88.6 billion in 2011 and RM94.1 billion in 2011, as reported by CIDB, 2012), which has further strengthened the nation's desire to grow.

The construction industry, which is among the most important industries in Malaysia, also significantly affects the nation's GDP. In fact, it was thought by Ibrahim et al. (2010) that every $10 \%$ rise in the productivity of the industry could increase about $2.5 \%$ of the national GDP. Nevertheless, the poorly performing industry has significantly affected its input, with statistics continuing to show a downward trend. GDP contributions have slumped from $17.3 \%$ in 1995 (see Ibrahim et al., 2010) to an average growth of $0.7 \%$ from 2000 to 2007 and an average input of only 3\% (CIMP, 2007), thus indirectly suggesting that current practices are inefficient and irrelevant to the country's ambition. In fact, the Director General of the Public Works Department of Malaysia once regarded the nation's construction industry to be in the 1960s in term of technologies (see Zaini, 2000) and, years later, the industry was still criticized due to poor practices such as the duplication of work, lengthy approvals, inefficient time and cost 
management, and lack of transparency (CIMP, 2007). All of these are synonymous with the inefficient traditional practices.

\section{PROJECT DELAY}

Time, in addition to cost and quality, is generally accepted as a measure of a project's success (Chan \& Chan, 2004). In principle, delay is any extra time taken to complete a project beyond the initial completion date that was set for the project, regardless of whose fault it is and at which stage the delay occurred. If the delay is the client's fault or occurred due to unexpected circumstances, a time extension is granted to the contractor, while if the cause involves contractor inefficiencies, liquidated ascertained damages are imposed on the contractor. Whoever is to blame, as long as the planned completion date is not met, the project is considered to be delayed; thus, proactive measures are needed to overcome this issue.

Project delay has been an extensively researched topic, with studies having surfaced literally from around the globe. These studies include those by Mansfield (1994) in Nigeria, Chan and Kumaraswamy (1997) in Hong Kong, and Al-Kharashi and Skitmore (2009) in Saudi Arabia. Within Malaysia, there have also been several public sector project studies; for instance, Shehu et al. (2015) took the perceptions of public and private sectors, contractors, clients, and consultants and compared them to a list of factors taken from the literature. Othman et al. (2006), on the other hand, determined the level of time performance in Malaysian public civil engineering projects at the time of their study and identified variables associated with the project characteristics and excusable delays that had a strong effect on the time performance of those projects. Despite these few studies, none specifically focused on delay factors in public sector projects from an expert's perspective, and none looked into the "pathogen" aspects of delay factors on which this research will focus (see Section 3.2).

\subsection{Delay: A Dilemma in the Malaysian Public Sector}

Public sector project delay is a major problem in Malaysia, with recent reports signifying that there is a deep problem in the approach the industry is taking. Within the last 15 to 20 years, delay rates have been enormous; for instance, a 78\% delay rate occurred within the years 2000-2005 (Abd Karim, 2008), and it was also reported that an average time extension of 171 days was issued per project. These projects could be labeled as "sick" projects (projects that are either delayed more than three months or abandoned). In 2009, performance was worse, with Joshi (2009) reporting an 80\% delay rate; the recently ended Tenth Malaysia Plan (from 2011 to 2015) was flooded with sick projects, whereby Jatarona et al. (2016) reported 235 sick projects in 2011 and 191 sick project in 2013. These scenarios send a strong message that current practices are no longer sufficient and current strategies are not effective in combating the delay dilemma.

\subsection{Delay Pathogens}

Inter-connected processes (Love et al., 1998) and the multi-disciplinary and multi-entity nature of the construction industry mean that delay occurrences should be made accountable to all parties; however, this has not always been the case. "Blame Game" has been seen as a culture that is embedded within each party whenever delay happens (e.g., Al-Khalil \& Al-Ghafly, 1999; Al-Kharashi \& Skitmore, 2009), meaning that people tend to transfer responsibility onto others whenever they are asked about the reason for a delay. For example, clients often blame contractors, and vice versa. This blame culture not only does not solve the problems; it also could lead to disputes, which certainly affect efficiency.

Past delay studies have also been linked to other shortfalls. AlSehaimi et al. (2012) pointed out the ineffective approaches taken in past delay research in which the identification of underlying reasons has been absent. In construction, pathogens are described as underlying conditions that 
are concealed within a system that are unidentifiable as long as problems as a result of these conditions have yet to occur (Busby \& Hughes, 2004). The pathogen approach is regarded as the principle step in order for process stability to be achieved (Love et al., 2008); thus, using this approach for delay studies not only helps to avoid repetition of similar mistakes; it also enables the problem to be tackled directly at its roots. To stop the incidence of future delays, it is vital that sources of pathogens are well-scrutinized (AlSehaimi et al., 2012). Taking the pathogen approach, which is known to suit any failure-related research (Busby \& Hughes, 2004), could be the potential savior, considering similar initiatives that have been taken to solve other project deficiencies, such as accidents (e.g., Reason, 1990) and disputes (Love et al., 2008). In fact, in a failure-related sense, delay is the failure to meet a pre-set completion date.

Busby and Hughes (2004, p. 429) divided the pathogens in their study into the following eight categories: (1) "Practice - Pathogens arising from people's deliberate practices"; (2) "TaskPathogens arising from the nature of the task being performed"; (3) "Circumstance Pathogens arising from the situation or environment in which the project was operating"; (4) "Convention - Pathogens arising from conventions, standards, routines, and codes of practice"; (5) "Organization - Pathogens arising from an organizational structure or operation"; (6) "System - Pathogens arising from an organizational system"; (7) "Industry Pathogens arising from the structural property of the industry"; and (8) "Tool - Pathogens arising from the technical characteristic of the tool". Within each of these categories, other sub-categories could arise, depending on the factors involved (see Busby \& Hughes, 2004). The pathogen approach categorizes a long list of factors into smaller group of latent conditions, which, according to Mehdi Riazi and Lamari (2013), not only makes the problem more manageable but also helps to avoid other problems related to particular pathogens arising in the future, since the very root of the issue will have been dealt with.

\section{SUPPLY CHAIN MANAGEMENT AS THE WAY FORWARD}

Fragmentation, a term that is synonymous with traditional practices, is regarded by Xue et al. (2005) as the main reason for the performance-related problems of Malaysia's construction industry. Beyond this, adversarial relationships, win-lose attitudes, poor transparency, and poor communication are among the weak connections of the industry (Palaneeswaran et al., 2003), and these have been responsible for problems such as poor time adherence in projects (e.g., Love \& Sohal, 2002). This has called for a revolution to achieve superiority over old practices (Ibrahim et al., 2010).

The Malaysian construction industry expertise is currently far behind (see Zaini, 2000) and is very much dominated by traditional practices (Abd Shukor et al., 2011). The need to improve practices has long been realized by the government; thus, initiatives to achieve this have begun taking place. However, many of the modern approaches are still very much traditionallyinfluenced (e.g., Nawi et al., 2010). One recent initiative, the Construction Industry Master Plan (CIMP) 2006-2015, also lacked innovative practices (Hamid \& Kamar, 2010); thus, industry performance is far from satisfying, and delay rates are still tremendously high.

The industry has long recognized the need to move away from traditional practices (e.g., Vrijhoef \& Koskela, 2000), and SCM has been regarded as a potential savior (e.g., Egan, 1998; Love et al., 2004). SCM's philosophy opposes the fragmented working environment and promotes integration as an integral aspect of a successful work environment. Collaboration is regarded as its "key driver" (Horvath, 2001), and firms need one another in order to survive in the complex environment of today's construction industry. The essential concept, elements and directions of SCM were also described via the following definition by Mehdi Riazi and Lamari (2013): 
"An innovative and revolutionary managerial approach which involves a working culture change and a voluntary initiated agreement for integration and synchronization of two or more inter-dependent members within variety organization level and boundaries as well as range of inter-linked construction life-cycle processes (initiation to handover). It promotes joint effort and strategy on all activities which are underpinned by mutual trust, responsibility, benefit and risk sharing based on a long-term perspective on relationship. Value is achieved through optimization and management of processes, resources, core competencies, talent, information, power and technology within the supply chain towards accomplishment of a set of shared objective and goals, enhance competitive advantage, breaking down any discontinuities and meeting distinctive client needs. Consequently, jointly agreed benchmarks, targets, expectation and values are put in place for continuous improvement efforts and are supported by aligned incentive schemes towards sustaining the endeavour."

As SCM is a serious topic, several other definitions have been introduced. For instance, Abd Shukor et al. (2009, p. 112) described SCM as "an integrated and collaborated supply chains whether upstream or downstream, inter or intra organization with the same goals and objectives for long term relationship integration," while according to Moore (1998, p. 172), SCM is "the links between the firm and its suppliers, through its distribution organisation and on to its customers." In short, it can therefore be concluded that in construction, SCM is " $a$ modern managerial philosophy which stands firmly on the need for continuous integration of two or more project parties from initiation to handover and throughout those phases value shall be achieved via joint initiatives, pooled resources, pain/gain sharing, mutual trust and a longterm perspective on relationship towards the accomplishment of a fixed set of mutual objectives."

While SCM has long been supported as a good public sector initiative (e.g., London \& Chen, 2006), for Malaysia, it remains rather a new concept (Rashid, 2002), with traditional practices still dominant (Abd Shukor et al., 2011), even in the CIMP 2006-2015 (Hamid \& Kamar, 2010). Nonetheless, the ability of SCM to improve construction performance (Horvath, 2001) and project management (Love et al., 2004) has been recorded. Additionally, its ability to improve the time performance of projects, including the British Airport Authority application (Brady et al., 2006) and the Heathrow T5 project (Potts, 2009), has also become evident via the application of certain tools. Therefore, inspired by the proven evidence and past success cases, cautious optimism exists that SCM could be the potential savior for the Malaysian public sector project's delay dilemma, provided that it stays in line with the industry's present trends (Abd Shukor et al., 2011).

\section{METHODOLOGY}

To propose a conceptual framework, this paper first identified the factors that cause delays in Malaysian public sector projects, grouped them into pathogens and sub-categories of pathogens, and then matched them with the proposed SCM tools from literature reviews that have been linked with the ability to overcome the respective pathogens and sub-categories of delay.

In a quest to identify the delay factors, semi-structured interview sessions were conducted with experts of the Malaysian construction industry to obtain a broad overview of the real-world scenario of the sector. Six respondents (two each from consultants, contractors, and the Public Works Department), all of whom possessed more than 20 years of experience in the industry, were selected for an interview. The characteristics the respondents used in this paper were justified with reference to a study by Ismail et al. (2014), who used a similar method in their paper entitled "Expert opinion on risk level for factors affecting time and cost overrun along the project lifecycle in Malaysian construction industry." In their study, the authors interviewed 
five experts with at least 10 years of experience handling projects. The current research has more respondents with more years of experience, thus justifying the number of samples and the status of the respondents as experts of the industry.

Later, results were analyzed using the content analysis method, and the factors identified were then grouped into pathogen and sub-pathogen categories by adapting and making sense of the concept that was used in the research by Busby and Hughes (2004). Lastly, beneficial SCM tools were identified from the literature review and suited with the relevant pathogen and pathogen sub-categories of delay that they have the ability to overcome. Some pathogens and sub-categories only had one tool that was suitable, while others had more than one, which gives practitioners the option to choose in their pursuit of overcoming delays in their projects.

\section{RESULTS AND DISCUSSION}

Table 1 presents the categorization of the delay factors obtained from the interview sessions conducted with the industry experts. With reference to the concept used by Busby and Hughes (2004), the factors were grouped into respective pathogens and pathogen sub-categories. The authors also adopted a qualitative approach in their research, which was converted into key points before its categorization. Therefore, this study took a similar approach; whenever any factor fit the previous authors' pathogen categorization, it was adopted. When none of the categories fit, new categories were proposed based on the understanding of the pathogen and its sub-category classification.

The grouping approach (please refer to Table 1) included factors such as "unrealistic project allocations and durations" and "one-sided contract conditions." These factors relate to the practice of satisfying the needs and targets of a project, such as adequate allocations, realistic completion times, and fair contract conditions. Thus, with reference to the definition by Busby and Hughes (2004), these factors were categorized under the pathogen "Practice" and the subcategory "Satisfaction." Another example is the grouping of "Blame Game' culture among project participants" and "Unpleasant and adversarial personality/attitude among project participants" under the pathogen "Circumstance" and the sub-category "Relationship" since they clearly portray poor relationships among the project members in the environment in which the project was operating. Other factors that did not fit into any of the sub-categories outlined by Busby and Hughes (2004) were assigned to new sub-categories through a similar approach.

Based on Table 1, 37 factors were identified from the interviews that were categorized into five pathogens, namely "Practice," "Task," "Circumstance," "Organization," and "Convention", all of which were adapted from Busby and Hughes (2004). These factors were then categorized into 15 sub-categories, whereby only four of them were adapted from Busby and Hughes (2004), namely "Prioritization," "Satisfaction," "Communication," and "Prediction." The rest"Coordination," "Designing," "Documentation," "Decision," "Dealing," "Relationship," "Responsibility," "Structure," "Competency," "Improvement," and "Bureaucracy"-were newly proposed sub-categories.

Overall, it was found that most of the factors (roughly one-third) were related to the pathogen "Practice." This finding is consistent with Busby and Hughes' (2004) study, whereby "Practice" was also the most dominant at 32\%. Errors have been linked to delays (Busby \& Hughes, 2004), which justifies the domination of the "Practice" pathogen in both studies. These findings further support past findings that inappropriate practices have dominated Malaysian public sector projects - i.e. traditional practices (see Abd Shukor et al., 2011) - that have long been linked with poor success (Karna \& Junnonen, 2005). 
The second most significant pathogen in this study, with seven factors, was "Convention." This finding contradicted that of Busby and Hughes (2004); in their study, "Convention" came in fourth place, at merely $12 \%$. This picture, however, can be explained by looking at the factors.

Table 1 Categorization of causes of delay into pathogens and pathogen sub-categories

\begin{tabular}{|c|c|}
\hline Sub-category & Delay Factors \\
\hline \multicolumn{2}{|c|}{ PATHOGEN 1: Practice - arising from people's deliberate practices } \\
\hline $\begin{array}{l}\text { Prioritization - Pathogens arising from } \\
\text { practices that determine priorities }\end{array}$ & 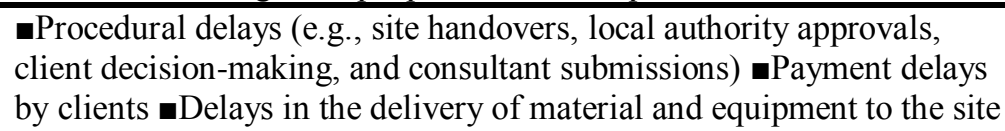 \\
\hline $\begin{array}{l}\text { Satisfaction - Pathogens arising from } \\
\text { practices related to satisfying goals, }\end{array}$ & $\begin{array}{l}\text {-Unrealistic project allocations and durations } \mathbf{m} \text { One-sided contract } \\
\text { conditions }\end{array}$ \\
\hline
\end{tabular}

needs, or targets

Communication - Pathogens arising from practices to do with acquiring or giving out information

* Coordination - Pathogens arising from practices to do with coordination * Designing - Pathogens arising from practices to do with designing or preparing drawings

* Documentation - Pathogens arising from practices to do with documentation

Prediction - Pathogens arising from practices used to make predictions
-Lack of communication between project participants

-Lack of coordination between project participants

-Improper project design

-Inconsistent project briefs $\mathbf{E}$ Improper project documentation

-Fluctuations in labor and material prices $\mathbf{m}$ Issues related to inclement weather Issues related to technical factors (e.g., unforeseen site conditions) $\square$ Shortage of resources (e.g., materials, plants, and labor)

\begin{tabular}{|c|c|}
\hline \multicolumn{2}{|c|}{ PATHOGEN 2: Task-arising from the nature of the task being performed } \\
\hline $\begin{array}{l}* \text { Decision - Pathogens arising from } \\
\text { tasks to do with making decisions }\end{array}$ & $\begin{array}{l}\text { Client-initiated variations and interference in projects } \mathbf{I m p r o p e r} \\
\text { project-planning tasks (e.g., unrealistic planning, allocations, or } \\
\text { durations) }\end{array}$ \\
\hline $\begin{array}{l}\text { * Dealing - Pathogens arising from } \\
\text { tasks to do with dealing with/coping } \\
\text { with/taking care of someone or } \\
\text { something }\end{array}$ & $\begin{array}{l}\text {-Problems dealing with the aboriginal community } \text { Issues related to } \\
\text { coping with a high number of public holidays } \text { assues related to } \\
\text { dealing with social/public issues (e.g., public interference, protests, or } \\
\text { social unrest) } \text { Issues related to project locality }\end{array}$ \\
\hline \multicolumn{2}{|c|}{ PATHOGEN 3: Circumstance - arising from the situation or environment in which the project was operating } \\
\hline $\begin{array}{l}\text { * Relationship - Pathogens arising from } \\
\text { circumstances to do with the } \\
\text { relationships among project members } \\
\text { * Responsibility - Pathogens arising } \\
\text { from circumstances to do with the } \\
\text { responsibilities of the project members }\end{array}$ & $\begin{array}{l}\text { "Blame Game" culture among the project participants "Unpleasant or } \\
\text { adversarial personalities/attitudes among the project participants (e.g., } \\
\text { disrespect, ego, or untrustworthiness) } \\
\text { aUnethical sub-contracting practices (e.g., "Ali Baba" and "Baba Ali") } \\
\text { aUnethical behavior (e.g., corruption and personal interests) or } \\
\text { political interference in projects }\end{array}$ \\
\hline \multicolumn{2}{|c|}{ PATHOGEN 4: Organization-arising from the organizational structure or operations } \\
\hline $\begin{array}{l}\text { * Structure - Pathogens arising from the } \\
\text { organizational structure } \\
\text { * Competency - Pathogens arising from } \\
\text { the competency of the organization } \\
\text { members }\end{array}$ & $\begin{array}{l}\text {-Incompetent project participants (e.g., lack of skills or knowledge) } \\
\text { Improper project supervision and management } \mathbf{m} \text { Pricing mistakes } \\
\text { made by contractors aInappropriate project implementation }\end{array}$ \\
\hline \multicolumn{2}{|c|}{ PATHOGEN 5: Convention - arising from the conventions, standards, routines, and codes of practice } \\
\hline $\begin{array}{l}\text { * Improvement - Pathogens arising } \\
\text { from the conventions of improving } \\
\text { practices }\end{array}$ & $\begin{array}{l}\text { Dependence on foreign labor } \text { aDependence on unskilled labor; Lack } \\
\text { of investment for Research \& Development } \text { Lack of personnel } \\
\text { training Inappropriate government policy practices (e.g., quota } \\
\text { requirements, staff transferring policies, or policy changes) }\end{array}$ \\
\hline $\begin{array}{l}\text { * Bureaucracy - Pathogens arising from } \\
\text { the industry's bureaucracy practices }\end{array}$ & $\begin{array}{l}\text { "Red Tape" practices within client and local authority organizations } \\
\text { (e.g., a multi-tiered formality in decision-making) } \text {-Procedural } \\
\text { problems (e.g., land acquisition or obtaining utility supplies) }\end{array}$ \\
\hline
\end{tabular}

* Newly proposed pathogen sub-categories 
that fell under this pathogen (refer to Table 1); these factors were mostly and quite specifically synonymous with the picture of the Malaysian construction industry. Labor shortages have long been a problem (e.g., Rajagopal, 2012); the country has been depending on foreign laborers to make up for this shortcoming. Foreign laborers are also mostly unskilled; thus, productivity is often lost due to the learning curves that must be overcome. The country's gross expenditure on research and development has also been very poor compared to many developed nations (see Siew \& Meng, 2010), while inappropriate government policies have also been evident, but these are very specific to Malaysia. The need to eliminate redundant bureaucracy, on the other hand, has been a major factor in contemporary managerial theory (Daniel \& Arthur, 2009); thus, its existence has not been good for project efficiency.

On the other hand, fair distribution was seen among the other three pathogens, with six factors in the "Task" pathogen. The two lowest contributing pathogens were "Circumstance" and "Organization," with five factors each. "Task" was the second most dominant pathogen in Busby and Hughes' (2004) study and came third in this study, which still supports the significance of this pathogen. Generally, construction activities are full of tasks that require proper undertaking; thus, it comes as no surprise that it has a major effect on the timely completion of construction projects.

\section{PROPOSING A CONCEPTUAL SCM FRAMEWORK TO REDUCE DELAY}

Based on the findings, a conceptual framework was developed. Beneficial SCM tools with the potential to deal with each pathogen sub-category were carefully identified from the literature and were then matched together to develop the framework, as presented in Table 2. The subcategories of the pathogens in Table 2 are an extension from Table 1 whereby only the respective sub-names are presented, since Table 1 already presents all the other details.

With reference to Table 2, relevant SCM tools were selected and matched by identifying them from the literature and scrutinizing their functions and possible roles in the mitigation of delay factors under each particular pathogen sub-category, as per Table 1. Under the framework, the most dominating SCM tool was "Jointly agreed goals" and "Pre-qualification using the "Team Criteria' score," which both suited five sub-categories. This was followed by "Profit \& risk sharing arrangements," which suited four sub-categories, while "Joint risk management" and "Regular joint review" were beneficial for three sub-categories.

Having mutual goals set during projects is highly encouraged in SCM (Maqsood et al., 2003), as it aids in effective collaborations (Eriksson \& Nilsson, 2008). Therefore, it comes as no surprise that this tool was one of the most dominating tools as per the framework in Table 2 and was found suitable for improving aspects related to collaboration and teamwork: "Prioritization," "Communication," "Coordination," "Relationship," and "Responsibility". This finding is in line with Mehdi Riazi (2014), who made sense of Oakland's TQM model and concluded that all five of these aspects are part of teamwork. This tool ensures that the team is focused on a set of objectives.

The other most dominant SCM tool was "Pre-qualification using the 'Team Criteria' score." This tool takes a "consortium" rather than individual company perspective when making evaluations and uses technical, relational, and sustainability scores as measures for evaluation (Kumaraswamy et al., 2007). This tool has the potential to overcome issues related to "Communication," "Coordination," "Relationship," "Structure," and "Competency" based on this study. Good team selection is vital for project success (Kumaraswamy et al., 2007) and ensuring that the right people are selected for the job; thus, participants exhibit better chemistry and attitudes, leading to better teamwork. The significance of this tool was evident whereby 15 
months' worth of time was saved during its application by the British Airport Authority (see Potts, 2009).

Table 2 Proposed conceptual SCM framework in order to reduce delays

\begin{tabular}{|c|c|c|}
\hline Sub-category & Proposed SCM Tools & References \\
\hline \multicolumn{3}{|c|}{ PATHOGEN 1: Practice_-arising from people's deliberate practices } \\
\hline \multirow[t]{2}{*}{ Prioritization } & Jointly agreed goals & - $\quad$ Maqsood et al. (2003) \\
\hline & - Profit \& risk sharing arrangements & - Eriksson and Pesämaa (2007) \\
\hline Satisfaction & - Joint risk management & - Kumaraswamy et al. (2004) \\
\hline Communication & Pre-qualification using the "Team Criteria" Score & - Kumaraswamy et al. (2007) \\
\hline$\& *$ Coordination & - Jointly agreed goals & - Maqsood et al. (2003) \\
\hline \multirow[t]{2}{*}{ * Designing } & - Building information modeling & - Holness (2008) \\
\hline & - Early involvement of the supply chain & - Kumaraswamy et al. (2004) \\
\hline *Documentation & - Regular joint review & - $\quad$ Ritchie and Brindley (2007) \\
\hline \multirow[t]{2}{*}{ Prediction } & - Joint risk management & - Kumaraswamy et al. (2004) \\
\hline & - Collaborative logistics & - Huang et al. ( \\
\hline \multicolumn{3}{|c|}{ PATHOGEN 2: Task-arising from the nature of the task being performed } \\
\hline \multirow[t]{2}{*}{ * Decision } & - Regular joint review & - $\quad$ Ritchie and Brindley (2007) \\
\hline & - Join & - $\quad$ Ritchie and B \\
\hline \multirow[t]{2}{*}{ * Dealing } & - Joint risk management & - Kumaraswamy et al. (2004) \\
\hline & - Joint pro-active assessment and planning & - $\quad$ Ritchie and Brindley (2007) \\
\hline \multicolumn{3}{|c|}{ PATHOGEN 3: Circumstance-arising from the situation or environment in which the project was operating } \\
\hline \multirow[t]{2}{*}{ * Relationship } & - Pre-qualification using the "Team Criteria" score & - Kumaraswamy et al. (2007) \\
\hline & Jointly agreed goals & - Maqsood et al. (2003) \\
\hline \multirow[t]{2}{*}{ * Responsibility } & Jointly agreed goals & - Maqsood et al. (2003) \\
\hline & - Profit \& risk sharing arrangements & - Eriksson and Pesämaa (2007) \\
\hline \multicolumn{3}{|c|}{ PATHOGEN 4: Organization-arising from the organizational structure or operations } \\
\hline * Structure & - Pre-qualification using the "Team Criteria" score & - $\quad$ Kumaraswamy et al. (2007) \\
\hline \multirow[t]{2}{*}{ * Competency } & Pre-qualification using the "Team Criteria" score & Kumaraswamy et al. (2007) \\
\hline & - Joint training and development program & - $\quad$ Ritchie and Brindley (2007) \\
\hline \multicolumn{3}{|c|}{ PATHOGEN 5: Convention—arising from conventions, standards, routines and codes of practices } \\
\hline \multirow[t]{2}{*}{ * Improvement } & - $\quad$ Profit \& risk sharing arrangements & - $\quad$ Eriksson and Pesämaa (2007) \\
\hline & - Regular joint review & Ritchie and Brindley (2007) \\
\hline * Bureaucracy & Profit \& risk sharing arrangements & Eriksson and Pesämaa (2007) \\
\hline
\end{tabular}

"Profit \& risk sharing arrangements" was slightly less prevailing compared to the previous two, but was still effective at improving "Prioritization," "Responsibility," "Improvement," and "Bureaucracy." This tool drives people to deliver by using a motivational approach in which the possibility of winning or losing pushes the project's parties to perform their best. In fact, better teamwork has been associated with responsibility sharing (Spekman et al., 1998); thus, priorities and responsibilities can be better managed while the fear of experiencing losses could motivate improvements and reduce "red tape" practices.

Two other SCM tools, "Joint risk management" and "Regular joint review," were significant in three sub-categories, as per Table 2 . The close connection between jointly managing risks and project performance is evident based on past applications of this tool; for instance, three months' worth of time was saved in a T5 project in the UK (see National Audit Office, 2005), and success was also found in the UK's M41 program (Kumaraswamy et al., 2004). "Regular joint review" represents several of the risk management responses proposed by Ritchie and Brindley (2007), which take advantage of joint effort in dealing with risks. The close connection between joint effort and project efficiency (Mehdi Riazi, 2014) supports the importance of this tool as a part of the initiative aimed to curb delays. 


\section{CONCLUSION}

While tremendous efforts have been made to combat the issue, construction project delay remains a recurrent scenario worldwide, including in Malaysia. Thus, it continues to be an important topic of research. In Malaysia, public sector project performance (i.e. timely completion) studies have been followed up with numerous initiatives due to the multiplier effect that the industry has on the growth of other sectors within the country; however, limited results have been achieved due to the domination of traditional practices within project implementation. Realizing the need to change and adopt contemporary approaches (i.e. SCM), Malaysia has followed suit in many calls for improvement that have been made worldwide. SCM has been suggested by many studies as the way forward and, with its proven success in past implementation, provides optimism from which Malaysia could also benefit. This paper used the industry's "expert opinions" as the approach to obtain an overview of real-world scenarios regarding the causes of delay in Malaysian public sector projects. These scenarios were then categorized into pathogens and pathogen sub-categories before a conceptual framework was proposed by matching suitable SCM tools in order to alleviate such pathogens. The final framework (please refer to Table 2) is anticipated to provide a holistic guideline for delay mitigation via SCM efforts for the supply chains involved in Malaysia's public sector projects. The detailed categorization and matching of tools can enable problems to be solved directly at their roots by utilizing the specific tools that are aimed to do such work.

\section{ACKNOWLEDGEMENT}

The authors would like to thank the Universiti Sains Malaysia Short-term Grant (Grant Number 304/PPBGN/6313279) for supporting this research.

\section{REFERENCES}

Abd Karim, J., 2008. Strategies of Effective Project Delivery System. Paper Presented at the School of Professional and Continuing Education, University of Technology, Malaysia

Abd Shukor, A.S., Mohammad, M.F., Mahbub, R., Hassan, F., Halil, F., 2009. Supply Chain Management: A Review of the Concepts and Success Factors. In: International Symposium on Construction in Developing Economies: Commonalities among Diversities, Penang, Malaysia

Abd Shukor, A.S., Mohammad, M.F., Mahbub, R., Ismail, F., 2011. Supply Chain Integration in Industrialized Building System in the Malaysian Construction Industry. The Built and Human Environment Review, Volume 4(1), pp. 108-121

Al-Khalil, M.I., Al-Ghafly, M.A., 1999. Delay in Public Utility Projects in Saudi Arabia. International Journal of Project Management, Volume 17(2), pp. 101-106

Al-Kharashi, A., Skitmore, M., 2009. Causes of Delays in Saudi Arabian Public Sector Construction Projects. Construction Management and Economics, Volume 27(1), pp. 3-23

AlSehaimi, A., Koskela, L., Tzortzopoulos, P., 2012. Need for Alternative Research Approaches in Construction Management: Case of Delay Studies. Journal of Management in Engineering, Volume 29(4), pp. 407-413

Brady, T., Davies, A., Gann, D., Rush, H., 2006. Learning to Manage Mega Projects: The Case of BAA Heathrow Terminal 5. In: IRNOP VII Project Research Conference, Xi' an, China

Busby, J.S., Hughes, E.J., 2004. Projects, Pathogens and Incubation Periods. International Journal of Project Management, Volume 22(5), pp. 425-434

Chan, A.P.C., Chan, A.P.L., 2004. Key Performance Indicators for Measuring Construction Success. Benchmarking: An International Journal, Volume 11(2), pp. 203-221 
Chan, D.W.M., Kumaraswamy, M.M., 1997. A Comparative Study of Causes of Time Overruns in Hong Kong Construction Projects. International Journal of Project Management, Volume 15(1), pp. 55-63

CIDB, 2012. Malaysia Country Report. In: The $18^{\text {th }}$ Asia Construct Conference, Marina Bay Sands, Singapore

Construction Industry Master Plan Malaysia (CIMP) 2006-2015., 2007. Construction Industry Development Board Malaysia (CIDB). Kuala Lumpur, Malaysia: CIDB

Daniel, W., Arthur, B., 2009. Chapter 10: The Emergence of the Management Process and Organization Theory. In: The Evolution of Management Thought $\left(6^{\text {th }}\right.$ ed.), Daniel, W. \& Arthur, B., (eds.), Wiley, Hoboken, New Jersey

Egan, J., 1998. Rethinking Construction: The Report of the Construction Task Force. DETR, London

Eriksson, P.E., Nilsson, T., 2008. Partnering the Construction of a Swedish Pharmaceutical Plant: Case Study. Journal of Management in Engineering, Volume 24(4), pp. 227-233

Eriksson, P.E., Pesämaa, O., 2007. Modelling Procurement Effects on Cooperation. Construction Management and Economics, Volume 25(8), pp. 893-901

Hamid, Z.A., Kamar, K.A.M., 2010. Modernising the Malaysian Construction Industry. In: P. Barrett, D. Amaratunga, R. Haigh, K. Keraminiyage, C. Pathirage (eds.), Proceedings of the $18^{\text {th }}$ CIB World Building Congress, Rotterdam, the Netherlands: CIB, pp. 267-280

Holness, G.V.R., 2008. BIM Gaining Momentum. ASHRAE Journal, Volume 50(6), pp. 28-40

Horvath, L., 2001. Collaboration: The Key to Value Creation in Supply Chain Management. Supply Chain Management: An International Journal, Volume 6(5), pp. 205-207

Huang, S.M., Kwan, I.S.Y., Hung, Y.C., 2001. Planning Enterprise Resources by Use of a Reengineering Approach to Build a Global Logistics Management System. Industrial Management \& Data Systems, Volume 101(9), pp. 483-491

Ibrahim, A.R., Roy, M.H., Ahmed, Z., Imtiaz, G., 2010. An Investigation of the Status of the Malaysian Construction Industry. Benchmarking: An International Journal, Volume 17(2), pp. 294-308

Ismail, I., Memon, A.H., Abdul Rahman, I., 2014. Expert Opinion on Risk Level for Factors Affecting Time and Cost Overrun Along the Project Lifecycle in Malaysian Construction Projects. International Journal of Construction Technology and Management, Volume 1(2), pp. $10-15$

Jatarona, N.A., Yusof, A.M., Ismail, S., Saar, C.C., 2016. Public Construction Projects Performance in Malaysia. Journal of Southeast Asian Research, Volume 2016, pp. 1-7

Joshi, M., 2009. 80 Per Cent of Malaysian Government Projects Delayed, Minister Says. Available Online at http://www.topnews.in/80-cent-malaysian-government-projectsdelayed-minister-says-2173299, Accessed on 1 October 2009

Karna, S., Junnonen, H., 2005. Project Feedback as a Tool for Learning. In: Proceedings of Conference of the International Group for Lean Construction (Volume 13), Sydney, Australia, pp. 18-21

Kumaraswamy, M., Love, P.E.D., Dulaimi, M., Rahman, M., 2004. Integrating Procurement and Operational Innovations for Construction Industry Development. Engineering, Construction and Architectural Management, Volume 11(5), pp. 323-334

Kumaraswamy, M.M., Ling, F.Y.Y., Anvuur, A.M., Rahman, M.M., 2007. Targeting Relationally Integrated Teams for Sustainable PPPS. Engineering, Construction and Architectural Management, Volume 14(6), pp. 581-596

London, K., Chen, J., 2006. Construction Supply Chain Economic Policy Implementation for Sectoral Change: Moving Beyond the Rhetoric. In: Proceedings of the Annual Research Conference of the Royal Institution of Chartered Surveyors, Brisbane, Australia: CRC for Construction Innovation, pp. 1-10 
Love, P.E.D., Davis, P., London, K., Jasper, T., 2008. Causal Modelling of Construction Disputes. In: Proceedings of the $24^{\text {th }}$ Association of Researchers in Construction Management ARCOM Conference, Cardiff, UK, pp. 869-878

Love, P.E.D., Gunasekaran, A., Li, H., 1998. Putting an Engine into Re-engineering: Toward a Process-based Organization. International Journal of Operations and Production Management, Volume 18(9), pp. 937-949

Love, P.E.D., Irani, Z., Edwards, D.J., 2004. A Seamless Supply Chain Management Model for Construction. Supply Chain Management: An International Journal, Volume 9(1), pp. 4356

Love, P.E.D., Sohal, A.S., 2002. Influence of Organisational Learning Practices on Rework Costs in Projects. In: Proceedings of the Eighth International Conference on ISO 9000 \& TQM (Change Management). Centre for Management Quality Research (CMQR) at RMIT University

Mansfield, N.R., 1994. Causes of Delay and Cost Overruns in Nigerian Construction Projects. International Journal of Project Management, Volume 12(4), pp. 254-260

Maqsood, T., Finegan, A.D., Walker, D.H., 2003. Extending Knowledge Management Across the Supply Chains in the Construction Industry: Knowledge Sharing in Construction Supply Chains. In: Second International Conference on Construction in the $21^{\text {st }}$ Century (CITC-II), Sustainability and Innovation in Management and Technology, Hong Kong

Mehdi Riazi, S.R., 2014. The Use of Supply Chain Management to Reduce Delays as a Result of Pre-construction Deficiencies in Malaysian Public Sector Construction Projects. Doctoral Dissertation, Queensland University of Technology

Mehdi Riazi, S.R., Lamari, F., 2013. Public Sector Project Delay: The Malaysian Perspective and the Way Forward. In: Proceedings of the $19^{\text {th }}$ CIB World Building Congress, Brisbane: Construction and Society, Queensland University of Technology

Moore, N., 1998. Supply Chain Management. Work Study, Volume 47(5), pp. 172-174

National Audit Office, 2005. Improving Public Services Through Better Construction. London: NAO

Nawi, M.N.M., Lee, A., Arif, M., 2010. The IBS Barriers in the Malaysian Construction Industry: A Study in Construction Supply Chain Perspective. In: TG57-Special Track $18^{\text {th }}$ CIB World Building Congress, Salford, United Kingdom, pp. 77-92

Othman, A.A., Torrance, J.V., Ab. Hamid, M., 2006. Factors Influencing the Construction Time of Civil Engineering Projects in Malaysia. Engineering, Construction and Architectural Management, Volume 13(5), pp. 481-501

Palaneeswaran, E., Kumaraswamy, M., Ng, S.T., 2003. Formulating a Framework for Relationally Integrated Construction Supply Chains. Journal of Construction Research, Volume 4(2), pp. 189-205

Potts, K., 2009. Construction Supply Chain Management: Concept and Case Study. Oxford: Blackwell

Rajagopal, M., 2012. Pekerja Sektor Binaan Kurang, Pemaju Terpaksa Rebut Tenaga Mahir untuk Laksana Projek RMKe-10 (Construction Sector Workers, Developers are Forced to Scramble for Skilled Manpower to Implement the $10^{\text {th }}$ Malaysia Plan Project), ETP, April 5, Berita Harian Newspaper

Rashid, K.B.A., 2002. Construction Procurement in Malaysia: Processes and Systems Constraints and Strategies. Research Centre, International Islamic University Malaysia

Reason, J., 1990. Human Error. Cambridge: Cambridge University Press

Ritchie, B., Brindley, C., 2007. Supply Chain Risk Management and Performance: A Guiding Framework for Future Development. International Journal of Operations and Production Management, Volume 27(3), pp. 303-322 
Shehu, Z., Holt, G.D., Endut, I.R., Akintoye, A., 2015. Analysis of Characteristics Affecting Completion Time for Malaysian Construction Projects. Built Environment Project and Asset Management, Volume 5(1), pp. 52-68

Siew, G.S., Meng, C.C., 2010. Bridging the Gap Between R\&D and Construction Industry. Available Online at http://gnpgeo.com.my/download/publication/2007_01.pdf, Accessed on March 3, 2012

Spekman, R.E., Kamauff, J.W. Jr., Myhr, N., 1998. An Empirical Investigation into Supply Chain Management: A Perspective on Partnerships. International Journal of Physical Distribution and Logistics Management, Volume 3(2), pp. 53-67

Vrijhoef, R., Koskela, L., 2000. The Four Roles of Supply Chain Management in Construction. European Journal of Purchasing and Supply Management, Volume 6(3), pp. 169-178

Xue, X., Li, X., Shen, Q., Wang, Y., 2005. An Agent-based Framework for Supply Chain Coordination in Construction. Automation in Construction, Volume 14(3), pp. 413-430

Zaini, O., 2000. Malaysian Construction Industry: Challenges and Demands. In: Malaysian Structural Steel Association Convention, Serdang 